ІСТОРИЧНІ ПЕРЕДУМОВИ ЗУНР

УДК 94 (477.83/86): 324 “1890/1914”

\title{
УКРАЇНСЬКА ГРОМАДА МІСТА СТАНИСЛАВОВА У ВИБОРЧОМУ РУСІ В ГАЛИЧИНІ (КІНЕЦЬ ХІХ - ПОЧАТОК ХХ ст.)
}

\author{
Ярослав КАПУЩАК \\ Державний вищий навчальний заклад \\ "Прикарпатський національний університет імені Василя Стефаника", \\ кафедра історії України і методики викладання історії \\ вул. Шевченка 57, 76018, Івано-Франківськ, Украӥна \\ e-mail: kapuschak.yarik@ukr.net \\ DOI: 10.15330/gal.32.9-23 \\ ORCID: 0000-0002-8824-790X \\ Андрій КОРОЛЬКО \\ Державний вищий навчальний заклад \\ "Прикарпатський національний університет імені Василя Стефаника", \\ кафедра історї Украӥни і методики викладання історії \\ вул. Шевченка 57, 76018, Івано-Франківськ, Украӥна \\ e-mail: korolko_andr@ukr.net \\ DOI: 10.15330/gal.32.9-23 \\ ORCID: 0000-0001-7435-5806
}

\begin{abstract}
У статті розкрито найважливіші віхи суспільно-політичного життя української громади м. Станиславів під владою Австро-Угорської імперії упродовж кіния XIX - початку ХХ ст.; простежено розвиток вічевого і страйкового рухів; проаналізовано ключові вимоги, які висувало украӥнство з метою захисту своїх прав від посягань панівних націй монархї; охарактеризовано участь українського населення міста у виборах до австрійського парламенту (рейхсрату) та Галицького крайового сейму досліджуваного періоду.
\end{abstract}

Ключові слова: украӥнська громада, місто, Станиславів, віче, вибори, посол.

В сучасній історичній думці все більш вагому роль перебирає на себе дослідження місцевої (локальної) історії, зокрема різноманітних аспектів вивчення літопису населених пунктів та визначення їхньої ролі у розвитку громадянського суспільства, окремих національних спільнот. Вивчення діяльності української громади м. Станиславова наприкінці XIX - на початку XX ст. в умовах бездержав'я, аналіз політики панівних народностей “клаптикової монархії” 3 центром у м. Відень об'єктивно сприятиме підвищенню розуміння українським суспільством цінності власної свободи, незалежності та посилюватиме прагнення до внутрішньої консолідації в непростих умовах сучасності.

Вітчизняна історична думка щодо вивчення питання участі українського населення м. Станиславов у виборчому русі в Галичині впродовж досліджуваного періоду не має цілісних спеціальних наукових праць. Окремі відомості 3 даної проблеми міститься у публікаціях українських дослідників I. Райківського ${ }^{1}$, Я. Грицака ${ }^{2}$, I. Чорновола ${ }^{3}$, В. Полєка ${ }^{4}$, а також

\footnotetext{
${ }^{1}$ Райківський I. Станиславів під австрійською владою (кінець XVIII - початок XX ст.). Галичина. Всеукрайнський науковий і культурно-просвітній краєзнавчий часопис. 2011. № 18/19. С. 11-25.

${ }^{2}$ Грицак Я. Нариси історії України. Формування модерної української нації ХІХ-XX ст. Київ : Генеза, 1996. $360 \mathrm{c}$.

${ }^{3}$ Чорновол І. 199 депутатів Галицького сейму. Львів, 2010. 228 с.

${ }^{4}$ Полєк В. Майданами і вулицями Івано-Франківська. Історико-культурний путівник. Львів : Світло і тінь, 1994. 89 c.
} 
польського історика С. Гродзіцького 5 . Тому австрійський період історії української громади міста Станиславова в умовах політизації українського національного руху потребує більш грунтовного дослідження.

У житті населення західноукраїнських земель під владою Австро-Угорської імперії кінця XIX ст. вагому роль відігравали такі чинники організації українства: участь у виборчому русі, проведення різного роду зібрань, народних віч, мітингів і маніфестацій, на яких українці намагалися відстояти свої права та інтереси від посягань панівних народностей монархії (поляків, німців) та висували певні вимоги покращення власного становища. Не винятком у цьому руслі стала діяльність й української громади м. Станиславів (сучасний м. Івано-Франківськ). Перебігу такого типу суспільно-політичних процесів сприяли підвищенню національної свідомості українців, слугували однією 3 передумов розгортання національного державотворення напередодні завершення Першої світової війни та періоду існування Західно-Української Народної Республіки (ЗУНР).

Отож, українська громада міста Станиславова включилася в процес політизації національного руху, головним виявом якого було скликання народних віч, зборів і маніфестацій.

Так, 15 (27) лютого 1890 р. було зізвано збори виборців у м. Станиславові, під час якого свій звіт виголосив посол до Галицького крайового сейму Йосиф Гурик (депутат цього законодавчого органу краю впродовж 1889-1895 та 1901-1907 рр. ${ }^{6}$. На зібрання прибуло більше 300 виборців і делегатів зі Снятинського, Товмацького, Монастириського, Надвірнянського, Богородчанського, Калуського та інших повітів, м. Тисмениці, а також 20 священиків. Й. Гурик ознайомив присутніх із діяльністю 16 українських послів Галицького крайового сейму; розповів про його склад і повноваження (151 посол, з яких $141 €$ виборними, 74 посли обиралися від т. зв. "меншої посілості" курії сільських громад, з них 48 - посли з “чисто руських" повітів, але українці мали тільки 16 мандатів); охарактеризував роботу "Руського клубу", утвореного 3 послів-українців на чолі з Юліаном Романчуком; повідомив донесення до депутатів і суспільства щодо фактів зловживань місцевих властей під час виборів до Галицького крайового сейму 1889 р.; тощо. Й. Гурик у своєму виступі зупинився на проблемних питаннях, які українські (“руські”) посли мали вирішити в майбутньому, наприкінці вислухав прохання і скарги від виборців ${ }^{7}$.

Після завершення зборів русини-українці Станиславівського виборчого округу направили до Клубу руських послів (“Руського клубу”) листа, адресованого на руки Ю. Романчука, в якому висловили сердечну подяку і цілковиту довіру щодо діяльності української депутації, “... Щоб Ви невтомно боронили природні права нашого народу”8.

8 грудня 1891 р. українська громада міста, - як повідомляла газета “Діло”, - мала намір скликати збори робітників і селян у справі загального виборчого права і свободи праці. Але староство заборонило організовувати зібрання, оскільки воно "могло викликати занепокоєння умів і $є$ шкідливим для загального добра"”.

У червні 1892 р. відомий український поет і громадсько-політичний діяч Іван Франко та Михайло Павлик в приміщенні по вул. Фердинанда (нині вул. Низова, 5) організували віче Русько-Української радикальної партії ${ }^{10}$. Спочатку зібрання мало відбутися у залі Зедельмаєра (нині вул. Новгородська), але міська влада в останню хвилину “залу цю визнала за небезпечну" для перебування в ній значної кількості людей. Тому збори відбулися у приміщенні лазні, хоч це, як написав кореспондент газети “Діло”, - “дуже недогідне місце”. У зборах взяли участь відомі громадсько-політичні діячі І. Гарасимович, С. Данилович, Я. Окуневський і К. Трильов-

\footnotetext{
${ }^{5}$ Grodziski S. Sejm krajowy galicyjski 1861-1914. Tom 2. Warszawa, 1993. 558 s.

${ }^{6}$ Grodziski Stanislaw. Sejm krajowy galicyjski... S. 188, 205.

${ }^{7}$ Посолъ Іосифъ Гурикъ передъ выборцями. Дгло. 1890. 20 лютого (4 марта). Ч. 40. С. 1-2.

${ }^{8}$ Адреса признаня клюбови рускихъ послоิвъ соймовыхъ оิдъ Русиноิвъ повъту станіславоิвского. Дгъло. 1890. 17 (29) марта. Ч. 62. С. 2.

${ }^{9}$ Новинки. Робоิтники въ Станіславовъ хотъли ще 8 грудня с. р. скликати зборы робоิтникоิвъ и селянъ въ справђ загального голосованя и свободы прасы. Дгло. 1891. 18 (30) грудня. Ч. 283. С. 3.

${ }^{10}$ Райківський І. Станиславів під австрійською владою... С. 22.
} 
ський. Місцевий урядовець заборонив проведення зібрання, а I. Франка і М. Павлика було притягнуто до відповідальності, проте суд їх виправдав ${ }^{11}$.

22 червня (4 липня) 1892 р. в місті відбулося чергове народне віче. Газета "Батьківщина" зауважила, що воно було досить численним - "учасників... могло бути тисяч душ; священиків до вісімдесяти”. Також у зборах взяло участь багато жінок, не тільки із середовища інтелігенції, але й простих селянок. Серед учасників присутніми були жителі Станиславівського, Калуського, Рогатинського, Товмацького, Надвірнянського, Богородчанського, Бучацького, Городенського повітів ${ }^{12}$. Нараду від імені місцевого комітету відкрив короткою промовою посол Й. Гурик, привітавши всіх присутніх ${ }^{13}$. Перший реферат виголосив адвокат із м. Львова, заступник голови Народної ради, уродженець м. Тисмениці Кость Левицький. Він представив "народну програму", прийняту на засіданні Народної ради в березні 1892 р. 3 промовами також виступили: адвокат з м. Стрия, голова "Підгірської ради" Євген Олесницький (про економічні справи); директор “Народної Торгівлі” Василь Нагірний (про громадське самоврядування); редактор газети “Діло” Іван Белей (про просвітницько-шкільні і політичні справи); депутат Йосиф Гурик (про потребу виборчої реформи) $)^{14}$.

Вартим уваги реферат "Постанови народні, що їх повинен знати на тепер кождий Русин”, виголошений К. Левицьким на цьому вічу. Політик відзначив, що український народ $є$ “нарід руський... самостійний нарід слов'янський... нарід давній, що має за собою минувшість історичну... Ми пережили часи, коли над нами панували князі і королі руські, ми ставали твердинею проти Татар і Турків, ми боролись за волю під Польщею і Росією, а нині рахують нас більше 20 мільйонів... [Ми] хочемо всебічного і вільного розвою нашої народності як самостійної народності слов'янської,'15.

Прийнято підсумкову ухвалу віча: розвивати і поширювати просвіту серед населення; дбати про народний добробут і достаток; єднатися і створювати нові українські товариства; через українських послів у парламенті намагатися вирішувати проблеми демократичним шляхом; наголошувалося на важливості імперської конституції 1867 р., яка “принесла нам великі свободи політичні і рівні права з іншими народностями Австро-Угорщини"; зазначалося, що народ руський хоче “жити в Австрії і бажає їй поваги поміж іншими державами світу”, що ми Русини "хочемо жити з нашими сусідами в згоді і на основі рівного права", і від нашого уряду “жадаємо конституційної оборони прав й інтересів народу руського" 16 .

Український депутат Й. Гурик проводив і надалі активну роботу з українськими виборцями міста. Так, на скликаному зібранні у залі Зедельмаєра по вул. Бельведерській 4 червня 1895 р. він звітував перед виборцями про свою парламентську роботу. На зборах були присутні 400-500 чол. та 10 священиків і представників світської інтелігенції. У своїй промові Й. Гурик розповів про роботу сейму та діяльність українських послів; звернув увагу на становище міського бюджету; охарактеризував шкільні та церковні справи; висвітлив вирішення питання регуляції рік, шляхів, ревізії земельного кадастру; висунув вимогу до крайового виділу з'ясувати причини загальної еміграції населення з Галичини. Після його виступу розпочалася дискусія, після чого присутні висловили свою довіру діяльності посла, та закликали всіх українців Станиславівського округу голосувати за нього на нових виборах до Галицького крайового сейму ${ }^{17}$.

Зауважимо, що наприкінці XIX - на початку XX ст. вибори відбувалися на основі застарілої куріальної системи, що була несправедливою, оскільки позбавляла права голосу більшість населення краю. Це забезпечувало відчутну перевагу провладним кандидатам, пред-

\footnotetext{
${ }^{11}$ Полєк В. Майданами і вулицями Івано-Франківська... С. 22.

${ }^{12}$ Віче в Станїславові. Батькоิвщина. 1892. 3 (15 липня). Ч. 27. С. 133.

${ }^{13}$ Въче народне въ Станиславовъ выпало вчера... Дгло. 1892. 23 червня (5 липня). Ч. 141. С. 1.

${ }^{14}$ Віче в Станїславові. Батьковвщина. 1892. 3 (15 липня). Ч. 27. С. 133-134.

15 Постанови народні, що їх повинен знати на тепер кождий Русин. Реферат д-ра Костя Левицкого на вічу в Станїславові. Батькоิвщина. 1892. 10 (22 липня). Ч. 28. С. 141

16 Там само. С. 141-142.

${ }^{17}$ Пос. І. Гурикъ передъ выборцями. Дгло. 1895. 24 мая (5 червня). Ч. 113. С. 2-3.
} 
ставникам заможних верств та категоріям тогочасного суспільства, тощо ${ }^{18}$. Окрім непропорційного представництва (трьом тисячам галицьких поміщиків (переважно поляків. - Авт.) гарантувалася майже третина місць у Галицькому сеймі, тоді як майже мільйон міщан не мали навіть половини), виборча система передбачала непрямі вибори у селянській курії. Під час голосування польська еліта ще додатково збільшувала своє представництво завдяки фальшуванням результатів виборів, підкупу або прямого тиску на селян. Безпосередньо перед голосуванням селянських виборців нерідко садили за столи, де коштом місцевої адміністрації і поміщиків їх щедро вгощали ковбасою і горілкою ${ }^{19}$.

Так, на виборах 1895 р. до Галицького крайового сейму на 47 мандатів із "руських" сільських виборчих округів Східної Галичини українці змогли вибороти лише 14 посольських місць, що було порівняно менше з попередніми виборами 1889 р., коли до сейму потрапило 16 українських депутатів. Решта 33 мандати дісталися в руки польській шляхті. Крім того, в середовищі українських “селянських" послів (а таких до сейму пройшло три, проти двох на попередніх виборах. - Авт.) кандидат Лазар Винничук, обраний зі Станиславівського виборчого округу, вважався пропольським ${ }^{20}$.

На виборах до сейму, які відбулися 25 вересня 1895 р., у Станиславівському виборчому окрузі переміг Лазар Винничук. Він отримав 91 голос із 162, на другому місці був дотеперішній посол селянин Й. Гурик, за нього віддали свої голоси 62 виборці ${ }^{21}$. До речі, Л. Винничук обирався депутатом Галицького крайового сейму впродовж кількох каденцій: 1895-1901, 1908 1913 та $1913-1914$ pp. $^{22}$.

Аналізуючи по гарячим слідам результати виборів 1895 р., невідомий дописувач часопису “Діло” відзначав, що до останньої миті кандидатура Й. Гурика активно підтримувалася українськими виборцями на зборах та вічах, і він мав шанси на перемогу. До того ж, Польський центральний комітет не виставив на Станиславівський виборчий округ свого кандидата, а місцеве староство спочатку дотримувалося правил ведення правиборів (обрання виборців серед населення, які згодом мали обирати послів. - Авт.). Проте пізніше представники польських політичних кіл підтримали кандидатуру війта з с. Угринова Станиславівського повіту Л. Винничука. За сприяння єврейської громади міста й околиць прихильники Л. Винничука активно застосовували брудну агітацію, не гребуючи передвиборчими махінаціями. Їм вдалося провести правибори в ряді сіл біля м. Станиславова на користь Л. Винничука. Поляки і євреї змогли забезпечити собі більшість у виборчій комісії, що дозволило їм в день виборів скасовувати голоси виборців на користь Й. Гурика через різноманітні “порушення”, переписувати їх 3 одного на іншого кандидата ${ }^{23}$.

Незважаючи на обрання пропольського депутата Л. Винничука до Галицького крайового сейму, активність української громади м. Станиславова у вирішенні питань суспільно-політичного, соціально-економічного і національно-культурного змісту лише посилювалася. 3 вересня 1896 р. в м. Станиславові, в залі Зедельмаєра, по вул. Бельведерській, відбулося народне повітове віче, на якому виступили: посол до австрійського парламенту Юліан Романчук із рефератом “про становище руського народу і прийдешні вибори до Ради державноі”; член крайової кадастрової комісії Йосиф Гурик про земельний кадастр; о. Ієронім Бариш про просвітницько-економічне становище українського населення м. Станиславова і Станиславівського повіту ${ }^{24}$. Це народне зібрання було організоване виділом львівської “Народної Ради” і місцевим станиславівським комітетом, до складу якого входили Й. Гурик та І. Бариш. На віче зійшлося

\footnotetext{
18 Райківський І. Станиславів під австрійською владою... С. 20.

${ }^{19}$ Грицак Я. Нариси історії України... С. 59-60.

${ }^{20}$ По выборахъ. Батькоิвщина. 1895. 16 (28) вересня. Ч. 18. С. 133-135.

${ }^{21}$ Кого выбрано до сойму зъ громадъ сьльскихъ? Батькоิвщчина. 1895. 16 (28) вересня. Ч. 18. С. 135.

22 Чорновол І. 199 депутатів Галицького сейму... С. 111, 113, 114.

23 Якъ перевелись выборы послоิвъ? Зъ Станиславова пишуть намъ... Дъло. 1895. 7 (19) жовтня. Ч. 225. С. $1-2$.

${ }^{24}$ Новинки и всячина. До всъхъ Русиноิвъ и всъхъ хлъборобоิвъ Станиславоิвского повђту! Батькоิвщинна. 1896. 16 (28) серпня. Ч. 16. С. 127.
} 
більше 600 чол., серед них - делегати громад Станиславівського та сусідніх повітів, селяни, духовенство і світська інтелігенція ${ }^{25}$.

Віче відкрив короткою промовою голова “Народної Ради” посол Ю. Романчук, в якій пояснив причини його скликання і подякував учасникам за їхню присутність. У своєму виступі він звернув увагу на політичний і соціально-економічний гніт українського народу у складі Австро-Угорщини. Політик наголосив, що на три мільйони українців в імперії припадає в кращому разі 17 послів до австрійського парламенту, якщо, в кращому випадку, українці повинні були б мати щонайменше 45 депутатів. У Галицькому крайовому сеймі така кількість українських депутатів мали б становити 63 посольські місця. Проте у Тимчасовому крайовому статуті австрійською владою було зафіксовано про можливість перебування у сеймі лише 47 українцівдепутатів. Однак, як зауважив Ю. Романчук, і такої кількості народних обранців не було у місцевому парламенті. В органах міського самоврядування і сільських громадах діловодство велося неукраїнською мовою. Проте Ю. Романчук закликав українців дисципліновано поставитися до нових виборів в австрійський парламент ${ }^{26}$.

Після виступу голови “Народної Ради” промову виголосив відомий громадсько-політичний діяч К. Трильовський. Він виокремив низку перешкод та утисків, які здійснює на різних рівнях влада Австро-Угорської імперії по відношенню до українців. На жаль, частина українських політиків, - за його словами, - стала прислуговувати владі заради власних інтересів, забувши про свій народ. Під час його виступу в залі почався безлад, К. Трильовського звинуватили в радикалізмі, а головуючий навіть погрожував йому судом, хоча селянство підтримало промовця. Й. Гурик відібрав слово у К. Трильовського, почавши говорити про кадастровий і земельний закони. Після нього знову виступив К. Трильовський, закликавши українців та політичні сили соціалістів, радикалів, народовців, старорусів (москвофілів) єднатися для спільної роботи на виборах ${ }^{27}$.

На виборах до австрійського парламенту 1897 р. в окрузі Станиславів-БогородчаниТовмач-Надвірна виборчий рух, за винятком Надвірнянського повіту, виявився доволі жвавим. 21 січня 1897 р. у м. Станиславові створено виборчий комітет. 3 п'ятої курії українською громадою міста було висунуто кандидатуру Й. Гурика ${ }^{28}$.

У цей час в селі Чернієві біля м. Станислава під час проведення т. зв. правиборів у п’ятій курії в рамках майбутніх виборів до австрійського парламенту, що відбулися 26 лютого 1897 р., було зафіксовано махінації, внаслідок яких до наступного кола вийшли польські кандидати. Це викликало обурення серед місцевого українського населення, яке оголосило протест і блокування правиборів до четвертої курії. До села було спрямовано чотирьох жандармів, які почали проводити арешти протестувальників. Розпочалися сутички, внаслідок яких один селянин загинув, а п'ятеро були поранені. Після цього для втихомирення населення прибув з військовим підрозділом станиславівський староста Прокопчиць ${ }^{29}$.

Упродовж 18-24 червня 1897 р. у м. Станиславові проводилося судове засідання стосовно “черніївської” справи. На ньому мали обрати покарання 25 селянам, звинуваченим у бунті і непослуху жандармам. Державна прокуратура переконувала суддівський корпус у тому, що селяни перешкоджали проведенню виборів. Коли жандарми почали арештовувати порушників, не давали їм вільно пройти, тому останні були змушені застосувати силу. Однак суд присяжних виправдав усіх обвинувачених селян, визнавши їх невинними ${ }^{30}$.

\footnotetext{
${ }^{25}$ Повътове въче народне въ Станиславовъ... Батькоิвщңина. 1896. 1 (13) вересня. Ч. 17. С. 130.

${ }^{26}$ Там само. С. $130-132$.

${ }^{27}$ Там само. С. $130-132$.

${ }^{28}$ Рухъ выборчій. Зъ Станиславова пишуть намъ: Въ окрузъ выборчомъ Станиславоิвъ-БогородчаныТовмачь-Надворрна рухъ выборчій - зъ выимкою повьта надвоิрняньского - досыть живый. Дгло. 1897. 25 сьчня (6 лютого). Ч. 20. С. 1.

${ }^{29}$ Рухъ політичный руского селяньства. Въ Черневъ пордъ Станиславовомъ мали воิдбути ся правыборы... Свобода. Письмо політичне, просвътне и господарске для народу. 1897. 27 лютого (11 марта). Ч. 9. С. 71.

${ }^{30}$ Ще процесы за выборы. ІІ. Справа черньъвска. Свобода. Письмо політичне, просвътне и господарске для народу. 1897. 19 червня (1 липня). Ч. 25. С. 194.
} 


\section{4}

За присутності військових частин відбулися правибори в інших приміських селах Угринів Долішній, Ямниця та Крихівці. В с. Угринові через махінації було обрано “хрунів" (продажні українці, які зрадили свій народ, виборців; прізвисько пішло від такого собі Микити Хруня. - Авт.). У селі орендар (“посесор”) барона Ромашкана єврейський кандидат Шміла тероризував селян, але отримав в підсумку лише п'ять голосів. Про результати правиборів невідомий дописувач часопису “Діло” так зазначав: “Громада с. Крихівці отримала 3 п'ятої курії добрих виборців, а з четвертої, - через інтриги жидів, - одного непевного"з1.

Підсумки виборів до австрійського парламенту 1897 р. були такі. 3 п'ятої курії округу Станиславів-Галич-Рогатин-Бурштин-Підгайці-Бучач-Золотий Потік-Тисмениця-Отинія український кандидат Й. Гурик поступився дідичу з м. Косова поляку Йосифу Богдановичу 456 голосів проти 469 голосів. Під час виборів було зафіксовано зловживання і махінації з боку поляків, євреїв та органів місцевої влади ${ }^{32} .3$ четвертої курії зі Станиславівського округу послом було обрано Корнилія Мандичевського, за якого проголосувало 428 виборців, Юліан Романчук отримав 238 голосів ${ }^{33}$.

10 лютого 1898 р. у м. Станиславові відбулося окружне народне віче, на якому обговорювалися такі питання: політичне становище українців в Австро-Угорській імперії; створення політичного товариства у Станиславівському повіті; розгляд шкільних справ ${ }^{34}$. За свідченнями дописувача газети “Свобода”, на віче з'явилося більше 1 тис. чол. Проводив зібрання о. I. Бариш. Першим слово взяв Й. Гурик, який розповів про діяльність повітової ради і прийняті нею постанови. Далі виступив І. Бариш стосовно потреби створення політичного товариства у м. Станиславові, де б для вирішення низки питань згуртувалися всі національно свідомі українці Станиславівського повіту. Після цього вдруге слово взяв Й. Гурик, який охарактеризував про жалюгідний стан народного шкільництва, з сумом відзначивши, що він не відповідає потребам українців краю. Ще один промовець Свген Левицький показав політичне становище українців Станиславівського повіту ${ }^{35}$.

На зборах прийнято підсумкову ухвалу, в якій були прийняті такі резолюції: віче протестує проти ідеї поляків щодо розширення автономії краю та вимагає широких прав іншим народностям; віче прагне поділу Галичини і приєднання до неї української частини Буковини в одноцільну національну територію; віче домагається впровадження загального безпосереднього і рівного виборчого права; віче висловлює подяку послам Т. Окуневському, С. Новаківському та Д. Остапчукові за їхній захист прав українців з трибуни. Наприкінці о. І. Бариш закликав посла Л. Винничука, який у Галицькому крайовому сеймі підтримував законопроекти поляків, самовільно скласти свій мандат ${ }^{36}$.

На зламі XIX і XX ст. число народних зібрань і маніфестацій у місті та передмісті Станиславова невпинно збільшувалося. Газета "Свобода" високо оцінила розвиток українського вічевого руху в Станиславівському повіті. Так, у першій половині 1900 р. відбулося по два віча в селах Черніїв і Павлівка, та одне у м. Станиславові. Невдовзі мали бути скликані народні збори в м. Галичі і в передмісті м. Станиславова с. Вовчинці $i^{37}$.

\footnotetext{
31 Зъ руху выборчого. Зъ Станиславова пишуть намъ: При асистенціи воิйска воิдбули ся правыборы въ селахъ поิдъ Станиславовомъ въ Угриновъ дольшноิмъ, въ Ямници и Крехоิвцяхъ. Дголо. 1897. 25 лютого(9 марта). Ч. 45. С. 2.

32 Выборы въ V-ой куріи. (VIII. Станиславоิвъ, Галичь; Рогатинъ, Бурштинъ; Поิдгайцъ, Вишнъвчикъ; Бучачь, Золотый Потоิкъ, Манастириска; Товмачь, Тисьмениця, Отинія). Дгло. 1897. 28 лютого (12 марта). Ч. 48. С. 1-2.

33 Новины. Высльдъ выбороิвъ зъ куріи четвертои... Свобода. Письмо політичне, просвътне и господарске для народу. 1897. 6 (18) марта. Ч. 10. С. 79.

34 Рухъ політичный, просвътный и економічный руского народу. Въ станіславоิвскомъ повђтъ. Дня 10 лютого воิдбуде ся въ Станіславовђ въче... Свобода. Письмо політичне, просвътне и господарске для на роду. 1898. 15 (27) съчня. Ч. 3. С. 22.

35 Въ станіславоิвскомъ повьтъ. Въче окружне зъ 10 лютого выпало дуже добре. Свобода. Письмо політичне, просвътне и господарске для народу. 1898. 12 (24) лютого. Ч. 7. С. 53-54.

${ }^{36}$ Въче въ Станиславовђ. Дгло. 1898. 6 (18) лютого. Ч. 28. С. 1.

${ }^{37}$ Просьвітний, економічний і політичний рух серед нашого народу. В Станїславівскім повіті проявив ся в послїдних часах сильний рух просьвітний, економічний і політичний. Свобода. Письмо політичне, просвътне и господарске для народу. 1900. 11 (24) мая. Ч. 19. С. 3.
} 
Станиславівський виборчий комітет, готуючись до нових виборів до австрійського парламенту, 18 жовтня 1900 р. затвердив “руським” кандидатом на п’яту курію Й. Гурика ${ }^{38}$. Перед виборами останній домігся аудієнції намісника Галичини Леона-Яна Пінінського, на якій довів про факти махінацій, незаконної агітації з боку урядових і польських кіл та недопущення селян до голосування під час проведення т. зв. правиборів. Він зазначив, що через це українці перестають вірити у верховенство права в Габсбурзькій монархії, бачачи, що все вирішує сила і підступ. Намісник відповів на це, що селяни самі винні, бо нібито “слухаючи агітаторів бунтують" і тому необхідно залучити до виборів військо і жандармерію. Проте Й. Гурик зауважив, що для цього не потрібно втручання збройних сил, якщо власті будуть діяти законними методами ${ }^{39}$.

На жаль, за результатами виборів до Державної ради наприкінці 1900 р. із п’ятої курії $з$ виборчого округу Станиславів-Товмач-Бучач послом був обраний поляк Ян Валевський. Він набрав 499 голосів, випередивши Й. Гурика, який отримав лише 439 голосів обранців ${ }^{40}$. У свою чергу, з четвертої курії округу Станиславів-Богородчани-Товмач-Надвірна посольський мандат виборов український священик пропольської орієнтації Корнелій Мандичевський, який набрав 385 голосів виборців. Його найближчі конкуренти націонал-демократ Йосиф Каранович та радикал Іван Бородайкевич отримали відповідно 249 та 36 голосів виборців ${ }^{41}$.

За підсумками чергових виборів до Галицького крайового сейму, які відбулися в 1901 p., зі Станиславівського округу послом було обрано Й. Гурика. Він отримав 120 голосів, а його опонент Л. Винничук - лише 46. Польський кандидат С. Брикчинський в останній момент зняв свою кандидатуру ${ }^{42}$. Результати голосування цих виборів українці біля міської ратуші прийняли зі щирим і глибоким натхненням, виконавши гімн "Ще не вмерла Україна" і псалом "Величай душе моя Господа" та гукаючи оклики “славно!”. Їхня радість була чутна по всій станиславівській площі Ринок. Після цього представники української громади міста вирушили вулицями Карпінського (нині вул. Галицька), Сапіжинською (нині вул. Незалежності), Липовою (нині вул. Т. Шевченка) і Собеського (нині вул. Січових Стрільців), прямуючи до будинку товариства "Руська Бесіда", де перед містянами виступив новообраний посол Й. Гурик. Звідти урочиста процесія рушила до катедральної церкви ${ }^{43}$.

Щоправда, проходження цих виборів у м. Станиславові мали і неприємний відтінок. Так, увечері 4 вересня 1901 р. п'яні “хруні” вчинили бійку з представниками української громади міста, одного з українців - В. Чубатинського - місцева влада навіть арештувала, тримаючи ув'язненим до ранку. Проте i “хруні” Іван та Микола Ясінські отримали доброго прочухана від патріотично налаштованих українців ${ }^{44}$.

12 грудня 1901 р. у м. Станиславові в театральній залі Товариства ім. С. Монюшка, відбулося народне віче. Головував на зібранні о. В. Озаркевич з с. Сілець Станиславівського повіту. Перший реферат про потребу українсько-руського університету у м. Львові зачитав о. І. Бариш. Для вирішення цього питання прийнято кілька резолюцій: поки не відкрито цей навчальний заклад, слід вимагати викладання у Львівському університеті дисциплін українською мовою; висловити щиру подяку патріотичній українській молоді за їі жертовність в організації цієї справи та українським послам за підтримку вирішення питання українського університету в

\footnotetext{
38 Дописи про виборчий рух. Зі Станїславівщини. (Більше кандидатів, як комітетових!) Свобода. Письмо політичне, просвътне и господарске для народу. 1900. 1 (25) жовтня. Ч. 41. С. 3.

${ }^{39}$ Виборчий рух. П. Йосиф Гурик хлопский кандидат на 5-ту курию Станіславів і т. д. ... Свобода. Письмо політичне, просвгттне и господарске для народу. 1900. 23 листопада (6 грудня). Ч. 47. С. 3-4.

${ }^{40}$ Чисельні викази з виборів (в V-ій куриі). Свобода. Письмо політичне, просвътне и господарске для народу. 1900. 8 (21) грудня. Ч. 49. С. 1-2.

41 Чисельні викази з виборів (в IV-тій куриі) Свобода. Письмо політичне, просвтьтне и господарске для народу. 1900. 8 (21) грудня. Ч. 49. С. 2.

42 Погром! Вибори в куриї хлопскій в рускій части краю... Свобода. Письмо політичне, просвътне и господарске для народу. 1901. 23 серпня (5 вересня). Ч. 34. С. 1.

${ }^{43}$ Повыборчй письма. Изъ Станиславова пишуть намъ.... Дгло. 1901. 30 серпня (12 вересня). Ч. 195. С. 2.

${ }^{44}$ Дописи. Зі Станїславівщини. "Разом сили сполучіте, добро буде вам”. Свобода. Письмо політичне, просвътне и господарске для народу. 1901. 30 серпня (12 вересня). Ч. 35. С. 3.
} 
16

парламенті. Під час дискусії слово взяли Ю. Олесницький, який говорив про діяльність академічної молоді, та посол Й. Гурик, вказавши на значення українського університету для всього народу. Наступний промовець селянин з с. Чернієва Мартин Королюк виступив про важке становище селянства. Віче закінчилось виконанням пісень "Ще не вмерла Україна" і "Не пора". Ввечері за сприяння музично-хорового товариства "Станиславівський Боян” відбувся концерт хору під керівництвом Євгена Якубовича ${ }^{45}$.

28 листопада 1905 р. у м. Станиславові, як і в інших містах Галичини, відбулися маніфестації з вимогою запровадження загального виборчого права. В театральній залі ім. С. Монюшка (нині Івано-Франківська обласна філармонія імені І. Маланюк) зібралося близько трьох тисяч чоловік. Під час першого виступу Лонгина Цегельського про виборчу реформу до зали ввійшли робітники, котрі також зібрались на віче на одній з площ міста. Після цього всі присутні у залі вийшли до центральної частини міста підтримати робітників, а потім повернулися назад до зали, де Л. Цегельський завершив свій виступ. Слово також взяв посол Й. Гурик. Він говорив про діяльність сейму, закликав до впровадження загального, рівного, безпосереднього виборчого права при таємному голосуванні. Під час дискусії виступив адвокат Зайнфельд, пояснивши, чому можновладці противляться новим реформам, та закликав селян до єдності з робітниками в боротьбі за рівність виборчого права ${ }^{46}$.

17 січня 1906 р. у передмісті Станиславова с. Чукалівка мало відбутися народне віче щодо розгляду нової виборчої реформи, але староста Прокопчиць заборонив його. Влада також не дозволила проведення подібних зібрань і в інших селах Станиславівського повіту ${ }^{47}$. Однак 21 січня 1906 р. все ж були проведені представницькі (“довірочні”) збори в селах Єзупіль (за участю 300 селян), Черніїв, Угринів Долішній (600 чол.), а 28 січня - Ямниця (близько 1000 чол.), на яких обговорювалася нова виборча реформа ${ }^{48}$.

30 січня 1906 р. у м. Станиславові відбулося окружне віче, на яке за різними оцінками зібралося від 8 до 10 тис. чол. Головою зборів обрано І. Бариша. Реферат про виборчу реформу виголосив делегат Народного комітету редактор газети “Діло” Є. Левицький. Прийнято такі резолюції: віче одноголосно вітає проголошення реформи на основі загального, рівного, безпосереднього і таємного голосування та домагається їі якнайшвидшого втілення у життя; віче протестує проти будь-яких заходів, які мають на меті дискримінацію прав українців щодо їхньої участі у виборах; віче протестує проти різного роду провокацій, згідно яких виборча реформа може бути зірвана. Після низки виступів промовців щодо виборчої реформи збори завершилися. Після цього учасники віче маніфестаційною колоною рушили через площу Ринок, вул. Карпінського (нині вул. Галицька), Третього Травня (нині вул. М. Грушевського) та площу Торговиці (нині вул. Військових ветеранів) ${ }^{49}$.

Виборча реформа 1907 р., дозволивши запровадити загальне право виборів до австрійського парламенту (мали право голосувати чоловіки віком від 24 років), помітно пожвавила політичне життя міста, сприяла залученню до нього ширших суспільних верств. Водночас вона була обмеженою, не стосувалася Галицького крайового сейму й органів місцевого самоврядування ${ }^{50}$.

У рамках цієї реформи австрійським урядом було розроблено нову геометрію виборчих округів. Так, в Галичині вони кількісно були поділені досить нерівномірно, через що значна частина голосів просто втрачалася. Наприклад, Станиславівський округ, який складався із судових повітів Отинія, Обертин, Товмач, Золотий Потік, Станиславів, Галич і Тисмениця,

\footnotetext{
453 народних віч і зборів. Віче в Станиславові відбуло ся д. 12 с. м... Свобода. Письмо політичне, просвътне и господарске для народу. 1901. 13 (26) грудня. Ч. 50. С. 2.

${ }^{46}$ Новинки. Народні віча в д. 28 падолиста. Дїло. 1905. 19 падолиста (2 грудня). Ч. 259. С. 3.

${ }^{47}$ Народні віча і манїфестациї. В станиславівскім повітї д. 17. с. м. мало відбути в Чукалівцї віче... Дїло. 1906. 9 (22) сїчня. Ч. 6. С. 2.

${ }^{48}$ Народні віча і манїфестациї. В станиславівскім пов. відбули ся д. 21. с. м. довірочні збори... Дїло. 1906. 17 (30) сїчня. Ч. 13. С. 2.

${ }^{49}$ Віча окружні. Віче окружне в Станиславові... Дїло. 1906. 18 (31) сїчня. Ч. 14. С. 2.

${ }^{50}$ Райківський І. Станиславів під австрійською владою... С. 21.
} 
обирав двох послів на 270925 осіб, а Бродівський округ, який теж складався 3 двох судових повітів, але обирав депутатів на 175206 чол. ${ }^{51}$.

Прийнятий проект реформи, як зазначала газета “Діло”, забезпечив полякам абсолютне панування в Галичині. Уряд гарантував передусім їхню присутність у міських округах, зліплених 3 міст, в яких польські виборці з євреями мали абсолютну більшість. Міста, в яких більшість могли становити українці, залишили в сільських округах. До того ж, австрійський уряд фактично додав польській національній спільноті мандати шляхом утворення в Західній Галичині дрібних округів. Відповідно, у Східній Галичині, де переважали українці, були створені надзвичайно великі округи. Але й цього полонофільському уряду виявилося замало. Було придумано спосіб, за яким поляки ще в кожному окрузі, де переважали українці, могли отримати один мандат. Так, один 3 кандидатів там мав набрати абсолютну більшість голосів, тоді як другому мало вистачити лише $25 \%$ голосів, саме стільки, скільки внаслідок штучного об'єднання поодиноких місцевостей у виборчий округ той буде мати польських і єврейських виборців. Тобто, українці могли не набрати і тих 18 посольських мандатів в австрійському парламенті, які залишилися станом на час проведення реформи (1907 р.) $)^{52}$.

Проте був і позитивний аспект - австрійський парламент, який десятками років обирався за куріальною системою виборів, припинив своє існування, новий виборчий закон отримав імператорську санкцію (підтвердження). Була окреслена нова схема виборів, базованих на загальному і безпосередньому голосуванні ${ }^{53}$.

Народний Комітет УНДП затвердив на вибори послів до австрійського парламенту з сільського виборчого округу № 59 (Станиславів, Обертин, Товмач, Золотий Потік, Галич, Тисмениця, Богородчани): як “кандидата більшості" адвоката у м. Станиславові Євгена Левицького; як "кандидата меншості" о. Алоїзія Олесницького, пароха в с. Чортовець Городенківського повіту та його заступника о. Ієроніма Бариша, пароха в с. Угринів Горішній ${ }^{54}$. Дещо раніше станиславівський осередок УНДП висунув на кандидата в австрійський парламент місцевого лікаря Володимира Яновича, а місцеві соціалісти - адвоката, єврея за національністю Зайнфельда ${ }^{55}$.

Цікавим $є$ i, на жаль, сумний факт передвиборчої агітації. Представники Української радикальної партії, які спершу погодилися на співпрацю з націонал-демократами під час виборів у двомандатному окрузі № 59, згодом почали активно агітувати не тільки за свого кандидата Лева Бачинського, але і проти Свгена Левицького. Український радикальний часопис "Громадський Голос" навіть називав останнього “ворогом" і “зрадником” селянської і загалом руської (української) справи. Радикали намагалися зірвати виступ $Є$. Левицького на вічу в с. Нижневі Товмацького повіту, ба, навіть сам Л. Бачинський під час виступу перед жителями у с. Ямниця Станиславівського повіту закликав голосувати проти українського кандидата від УНДП ${ }^{56}$.

17 травня 1907 р. відбулися вибори до австрійського парламенту. У сільському окрузі № 59 голосувало 47932 чол. Голоси виборців були розподілені таким чином: “кандидат більшості” Є. Левицький (УНДП) отримав 10 558, “кандидат меншості” (УНДП) о. А. Олесницький - 2 706, радикал Л. Бачинський - 19 870, москвофіл Лев Алексєвич - 5150, соціал-демократ Зайнфельд - 2 426. У першому турі виборів ніхто не був вибраний. Нові вибори в окрузі були призначені на 24 травня $^{57}$.

\footnotetext{
${ }^{51}$ Виборчі округи. ІІІ. Дїло. 1906. 10 (23) марця. Ч. 47. С. 1.

${ }^{52}$ Виборчі округи в Галичинї. Дїло. 1906. 30 мая (12 червня). Ч. 109. С. 1.

${ }^{53}$ Відозва. Новий виборчий закон одержав цісарску санкцію. Свобода. Полїтична, просьвітна $i$ господарска часопись. 1907. 14 лютого. Ч. 7. С. 1-2.

${ }^{54}$ Оголошенє. Народний Комітет яко начальна екзекутива народного (національно-демократичного) сторонництва... Дїло. 1907. 20 цьвітня. Ч. 80. С. 1.

55 Передвиборчий рух. 3 міста Станиславова. Руським кандидатом з міста Станиславова поставила тамошна органїзация місцева... Дїло. 1907. 21 марця. Ч. 54. С. 2.

${ }^{56}$ Передвиборчий рух. В справі акциї виборчої в окрузї Станиславів-Товмач-Обертин і т. д. одержали ми слїдуючу статю... Дїло. 1907. 4 мая. Ч. 90. С. 2-3.

${ }^{57}$ Кілько хто дістав голосів дня 17 с. м. Свобода. Полїтична, просьвітна і господарска часопись. 1907. 21 мая. Ч. 21. С. 2.
} 
Тим часом, станиславівський осередок УНДП на нараді 20 травня 1907 р., вирішив при “тіснішому виборі” посла 3 міста Станиславова зняти кандидатуру В. Яновича і віддати ці голоси на користь кандидата від сіоністів єврея Маркуса Бравда на противагу інженеру Павлу Ствєртні, колишньому члену "Кола польського" в австрійському парламенті. Такі ж наміри висловили й місцеві соціал-демократи ${ }^{58}$. Часопис “Діло” повідомляв, що 3 м. Станиславова до рейхсрату було обрано П. Ствєртню. Водночас, не обійшлося без корупції, крадіжок голосів та різного роду інших методів “політичної боротьби”. Новообраний посол, за вказівкою старости Прокопчиця, активно агітував в сільському окрузі за “народним” кандидатом А. Ценським

Під час другого голосування 24 травня 1907 р. результати були такі: Є. Левицький отримав 13183 голоси, Л. Бачинський - 20 710, поляк Адольф Ценський - 6 222, Л. Алексєвич 3132 голоси. Оскільки ніхто не отримав більшості, повинно було відбутися третє голосування, де кандидатами залишилося троє, які набрали найбільшу кількість голосів виборців,Л. Бачинський, Є. Левицький і А. Ценський ${ }^{60}$.

Тільки за третім разом було обрано послів 3 двомандатного виборчого округу № 59. Український радикал Л. Бачинський отримав 19385 голосів, націонал-демократ Є. Левицький 16732 , а поляк А. Ценський $-7268^{61}$.

Отже, за результатами виборів до австрійського парламенту 1907 р. увійшли 32 українські посли, серед яких 5 із Буковини і 27 з Галичини (серед них 17 націонал-демократів, 3 радикали, 2 соціал-демократи та 5 москвофілів). Зі Станиславівського виборчого округа № 59 мандати вибороли Л. Бачинський та Є. Левицький ${ }^{62}$.

У лютому 1908 р. відбулися чергові вибори до Галицького крайового сейму. 374 сільських округів, в яких було проведено голосування, в 47 переважало українське населення (Східна Галичина), а в 27 польське (Західна Галичина). Однак польських послів було обрано аж 53, українських - лише 11 (8 членів УНДП і 3 УРП), а також 9 москвофілів. У Станиславівському виборчому окрузі був обраний селянин Л. Винничук, який висунув свою кандидатуру в останній момент. Він отримав 127 голосів, а його конкурент український радикал Мартин Королюк $-83^{63}$.

3 міського округу Станиславова обрано польського консерватора Л. Білінського. За нього проголосувало 920 виборців із 1207 , а за його конкурента, опозиційного кандидата М. Зайончека $-287^{64}$.

На нові вибори до складу австрійського парламенту 1911 р., у виборчому окрузі № 59, було висунуто такі кандидатури: від українських націонал-демократів Євген Левицький, від українських радикалів Лев Бачинський, від українських соціал-демократів Юліан Бачинський, від москвофілів Лев Алексєвич. Були й пропольські кандидати-висуванці - це учитель 3 передмістя Станиславова с. Микитинці Йосиф Струтинський та Цюцяк, війт з с. Радча Станиславівського повіту. Поляки, у свою чергу, на зборах, які відбулися 24 квітня 1911 р. в залі станиславівського "Сокола", обрали свій виборчий комітет й обговорили питання висунення можливих кандидатів. Серед них - станиславівський віце-маршалок Станіслав Ценський, товмацький маршалок Станіслав Богданович та граф з с. Єзупіль Станиславівського повіту Владислав Дзєдушицький ${ }^{65}$.

\footnotetext{
58 Вибори. 3 міста Станиславова: Станиславівська місцева органїзация нашого национально-демократичного сторонництва рішила... Свобода. Полїтична, просьвітна $і$ господарска часопись. 1907. 23 мая. Ч. 104. С. 2.

${ }^{59}$ Вибори. Виборчі розбої. Із Станиславова доносять... Дїло. 1907. 30 мая. Ч. 110. С. 2.

${ }^{60}$ Оповіщенє з округа виборчого ч. 59. Свобода. Полїтична, просьвітна і господарска часопись. 1907. 28 мая. Ч. 23. С. 3.

${ }^{61}$ Вибори в 1907-ім роцї. Округ 59. Станиславів, Товмач і т. д. Свобода. Полїтична, просьвітна $i$ господарска часопись. 1911. 3 мая. Ч. 19. С. 5.

6232 руских послів в австрійскій державній радї. Свобода. Полїтична, просьвітна і господарска часоnись. 1907. 6 червня. Ч. 25. С. 5.

${ }^{63}$ Вчерашні вибори. Дїло. 1908. 13 (28) лютого. Ч. 43. С. 1.

${ }^{64}$ Вибори з галицьких міст. Дїло. 1908. 19 лютого (3 марця). Ч. 48. С. 1.

${ }^{65}$ Виборчий рух. 3 округа 59-ого (Станиславів, Товмач і т. д.). Свобода. Полїтична, просьвітна і господарска часопись. 1911. 5 мая. Ч. 20. С. 3.
} 
19 червня 1911 р. відбулося перше голосування в рамках виборів до австрійського парламенту. В окрузі № 59 голосувало 45760 чол. Є. Левицького підтримало 15461 виборець, українського радикала Л. Бачинського 14 724, Л. Алексєвича 4 310, В. Дзєдушицького 9947 , Ю. Бачинського 1 550, Цюцяка 547, Й. Струтинського 159 виборців. 26 червня мав відбутися другий тур голосування, оскільки ніхто 3 кандидатів не набрав більшості голосів ${ }^{66}$.

У цей час в міському окрузі № 14 (Станиславів) голосувало 4835 виборців. Едмунд Равх (польський демократ “Ради народової”) отримав 3 590, Павло Ствєртня (польський демократ) - 947, Ціппер (сіоніст) - 1 152, В. Янович (УНДП) - 94 голосів. До рейхсрату обрано Е. Равха ${ }^{67}$.

Під час другого туру голосування на парламентських виборах в окрузі № 59 були зафіксовані такі результати: Є. Левицький набрав 15 151, Л. Бачинський 16 192, Л. Алексєвич 2837 голосів. У виборах взяло участь 35138 чол. $^{68}$.

3 липня 1911 р. відбувся третій тур голосування. В Станиславівському сільському окрузі Є. Левицький отримав 15375 , Л. Бачинський -15637 і Л. Алексевич -703 голоси ${ }^{69}$.

За результатами виборів до парламенту 1911 р. 328 руських округів Східної Галичини було обрано 24 українські посли, 2 москвофіли і 2 поляки. 3 округу № 59 мандати отримали Л. Бачинський та Є. Левицький. 3 24-х українських послів 18 належало до УНДП, 5 до УРП, та 1 до УСДП. 3 Буковини, як і на попередніх виборах, пройшло п'ять українських депутатів ${ }^{70}$.

Обидва репрезентанти Станиславівщини в рейхсраті входили до української фракції (“клубу”), що складалася з націонал-демократів і радикалів Галичини й Буковини. Особливо прославився своїми парламентськими промовами Л. Бачинський, який був одним 3 найкращих ораторів тодішньої Галичини. Василь Стефаник називав його “промовцем-поетом”. Для того, щоб привернути увагу парламенту до проблем українців Л. Бачинський вдався до т. зв. “обструкційної промови” (оскільки тривалість виступу посла фактично не обмежувалася регламентом, треба було тільки дотримуватися відповідної теми обговорення) ${ }^{71}$.

Відомий радикальний діяч Іван Макух писав у своїх спогадах, що Л. Бачинський установив європейський рекорд тривалості парламентського виступу, промовляючи безперервно протягом майже 14 годин (його слухачами залишилися тільки головуючий і стенографісти, а депутати змушені були розійтися) $)^{72}$.

Попри розгляд важливих політичних і соціально-економічних питань в австрійському парламенті, окремі $з$ них обговорювалися і на народних зібраннях української громади м. Станиславова. 12 лютого 1912 р. в місті, на площі українського “Сокола" по вул. Третього Травня (нині вул. М. Грушевського), відбулося зібрання з питань впровадження виборчої реформи до Галицького сейму. Головою віча обрано Михайла Губчака, а секретарем Дмитра Вітовського. Майдан заповнився січовиками, селянами, кількома представниками станиславівської інтелігенції. Про стан справ щодо виборчої реформи говорили українські посли I. Макух та Л. Бачинський. Вони також висловлювалися за надання виборчого права жінкам ${ }^{73}$.

19 травня 1912 р. у м. Львові у залі "Руської Бесіди" пройшло віче у справі заснування українського університету. Присутніх на зібранні було лише 400 чол., оскільки про збори

\footnotetext{
${ }^{66}$ Виказ голосованя. Округ 59. Станиславів, Товмач і т. д. Свобода. Полїтична, просьвітна і господарска часопись. 1911. 21 червня. Ч. 32. С. 2.

${ }^{67}$ Вибори в Східній Галичинї. Мійські округи. Округ 14. Дїло. 1911. 8 (21) червня. Ч. 135. С. 3.

${ }^{68}$ Виказ другого голосованя 3 дня 26-го с. м. в сих округах, де в сей понедїлок, дня 3-го липня маємо вибрати 18 наших послів. (Округ 59. Станиславів-Товмач-Обертин і т. д). Свобода. Полїтична, просьвітна і господарска часопись. 1911. 29 червня. Ч. 34. С. 3.

69 Кінець виборів в Східній Галичинї. Округ виборчий ч. 59. (Станиславів, Товмач, Богородчани, Єзупіль). Дїло. 1911. 21 червня (4 липня). Ч. 146. С. 2.

${ }^{70} 24$ українські посли... Свобода. Полїтична, просьвітна і господарска часопись. 1911. 6 липня. Ч. 35. С. 1.

${ }^{71}$ Райківський І. Станиславів під австрійською владою... С. 21-22.

72 Там само.

73 Дня 12. лютого с. р. о 12. год. в полудне відбуло ся в Станиславові віче під голим небом в справі соймової виборчої реформи. Дїло. 1912.3 (16) лютого. Ч. 36. С. 3.
} 
належним чином не було повідомлене населення. Зібрання відкрив Юліан Олесницький. Реферат про стан справ стосовно відкриття українського університету виголосив Л. Бачинський. Далі слово взяв Ю. Олесницький, який закликав український народ до боротьби за свої законні права. Прийнято такі резолюції: віче домагається якнайшвидшого заснування українського університету, оскільки тільки цей крок може задовольнити національно-культурні потреби українського народу; віче висловило довіру і подяку українському парламентському клубу за його зусилля в даній справі; збори виголосили своє обурення тим професорам Львівського університету, які намагалися провокувати і розпалити ворожнечу між українською і польською студентською молоддю ${ }^{74}$.

На нові вибори до Галицького крайового сейму в 1913 р., Народний комітет УНДП затвердив зі Станиславівського сільського округу Л. Винничука - війта 3 передмістя Станиславова села Угринів Долішній ${ }^{75}$.

30 червня 1913 р. відбулося голосування з курії сільських громад в 74 виборчих округах, $з$ яких 47 припадало на Східну Галичину, а решта 27 - на Західну. У Станиславівському окрузі голосувало 222 виборці. Український кандидат від націонал-демократів Л. Винничук отримав 211 голосів, а його конкурент польський ксьондз Ангер - лише 11. Отже, посольський мандат дістався українському кандидату ${ }^{76}$.

Згідно загальних результатів виборів, український національний табір отримав 30 представників у сеймі. Москвофіли отримали лише 2 мандати, а поляки -15.330 українських послів 23 належали до націонал-демократів, 6 - до радикалів і 1 -безпартійний ${ }^{77}$.

Активне життя української громади міста перервала Перша світова війна. Вже 3 серпня 1914 р. була утворена міжпартійна організація, яка дістала назву Головна Українська Рада, на чолі з Костем Левицький, та його заступниками Михайлом Павликом та Миколою Ганкевичем. У своій відозві до українського народу вона закликала підтримувати Австро-Угорщину у ії військовому конфлікті з одвічним ворогом України Російською імперією. В документі зазначалося, що “... на руїнах царської імперії зійде сонце вільної України!”, тобто, здійсниться давнє прагнення нашого народу одержання власної державності ${ }^{78}$.

Отже, українське населення м. Станиславова й околиць наприкінці XIX - на початку XX ст. взяло активну участь у виборчому русі Австро-Угорської імперії. Завдяки висуненню кандидатів до складу таких політичних установ Габсбургської монархії як рейхсрат і Галицький крайовий сейм, українство могло убезпечити себе від асиміляції з боку панівних народностей “клаптикової” імперії (німців, поляків та ін.). Українські депутати різних політичних партій та організацій, які змогли у нелегкій боротьбі вибороти місце в органах влади, об'єднувалися там у своєрідні спілки-клуби, які тільки спільними зусиллями могли захистити інтереси власного народу. Крім цього, важливою частиною суспільно-політичного життя станиславівських містян та жителів його околиць стала організація і проведення різного роду народних віч, зібрань, маніфестацій. На них виголошувалися промови, висувалися вимоги та ухвалювалися резолюції на підтримку політичних, соціально-економічних і національно-культурних вимог українського народу, що прагнув отримати ті ж права, якими вже багато років користувалися поляки, угорці та інші “сильні" народи у складі імперії. У недалекому майбутньому, через кілька років в умовах розгортання української національної революції 1917-1923 pр., такі зібрання стали важливим чинником для створення єдиної соборної Української держави.

\footnotetext{
${ }^{74}$ Вічевий рух. Дїло. 1912. 11 (24) мая. Ч. 115. С. 5.

${ }^{75}$ Наші кандидатури. Свобода. Полїтична, просьвітна і господарска часопись. 1913. 25 червня. Ч. 26. C. 2.

${ }^{76}$ Вибори з сїльської куриї. Свобода. Полїтична, просьвітна і господарска часопись. 1913. 3 липня. Ч. 27. C. 2.

${ }^{77}$ Вчерашні вибори. Дїло. 1913. 18 червня (1 липня). Ч. 144. С. 1-3.

78 Український Народе! Дїло. 1914. 21 липня (3 серпня). Ч. 171. С. 1.
} 


\title{
UKRAINIAN COMMUNITY OF THE CITY OF STANYSLAVIV IN ELECTORAL MOVEMENT IN GALICIA (END XIXth - BEGINNING OF THE XXth CENTURY)
}

\author{
Yaroslav KAPUSHCHAK \\ State Higher Educational Institution \\ "Vasyl Stefanyk Precarpathian National University", \\ Department of History of Ukraine and methods of teaching history, \\ Shevchenko St., 57, 76018, Ivano-Frankivsk, Ukraine \\ e-mail: kapuschak.yarik@ukr.net \\ Andrii KOROLKO \\ State Higher Educational Institution \\ "Vasyl Stefanyk Precarpathian National University", \\ Department of History of Ukraine and methods of teaching history, \\ Shevchenko St., 57, 76018, Ivano-Frankivsk, Ukraine, \\ e-mail:_korolko_andr@ukr.net
}

\begin{abstract}
Summary
The article describes the most important milestones in the social and political life of the Ukrainian community of Stanyslaviv under the rule of the Austro-Hungarian Empire during the late XIXth and early XXth centuries; the development of eternal and strike movements in the environment of our people is traced; the key requirements that Ukraine has advanced in order to protect its rights against the encroachments of the ruling nations of the Habsburg monarchy have been analyzed; the participation of the Ukrainian population of the city in the elections to the Austrian Parliament (Reichsrat) and the Galician Regional Seim of the study period is characterized. Thus, in particular, among the basic requirements of the Ukrainian community of Stanyslaviv, which were put forward at various meetings and demonstrations, and were vital for our people as a whole, are the following: to divide Galicia into Western (Polish) and Eastern (Ukrainian) parts by providing autonomy to the peoples of the region; to introduce universal equal suffrage to the Halych Regional Seimas and the Reichsrat; to open a university in the city of Lviv with the Ukrainian language of teaching, etc. The article also describes the activities of well-known socio-political figures of the Ukrainian people associated with Stanyslaviv, who contributed to raising the awareness of the population and the deployment of the Ukrainian national movement. Among them: Joseph Guryk, Ivan Franko, Kost Levytsky, Lev Bachynsky, Yevgeny Levytsky, Jerome Barish, Dmytro Vitovsky, Volodymyr Yanovych and others.

The course of this type of socio-political processes in the environment of the Ukrainian community of Stanyslaviv contributed to the raising of national consciousness of Ukrainians, served as one of the prerequisites for the deployment of national state formation before the end of World War I and the period of existence of the Western Ukrainian People's Republic (ZUNR).
\end{abstract}

Keywords: Ukrainian community, city, Stanyslaviv, Chamber, elections, ambassador.

\section{REFERENCES}

Raikivskyi I. Stanyslaviv pid avstriiskoiu vladoiu (kinets XVIII - pochatok XX st.). Halychyna. Vseukrainskyi naukovyi i kulturno-prosvitnii kraieznavchyi chasopys. 2011. № 18/19. S. 11-25. [in Ukrainian]. Chornovol I. 199 deputativ Halytskoho seimu. Lviv, 2010. $228 \mathrm{~s}$.

Poliek V. Maidanamy i vulytsiamy Ivano-Frankivska. Istoryko-kulturnyi putivnyk. Lviv : Svitlo i tin, 1994. 89 s. [in Ukrainian].

Hrytsak Ya. Narysy istorii Ukrainy. Formuvannia modernoi ukrainskoi natsii XIX-XX st. Kyiv :

Heneza, 1996. 360 s. [in Ukrainian].

Grodziski Stanislaw. Sejm krajowy galicyjski 1861-1914. Tom 2. Warszawa, 1993. 558 s. [in Poland].

Posol Iosyf Huryk pered vybortsiamy. Dilo. 1890. 20 liutoho (4 marta). Ch. 40. S. 1-2. [in Ukrainian].

Adresa pryznania kliubovy ruskykh posliv soimovykh od Rusyniv povitu stanislavivskoho. Dilo. 1890.

17 (29) marta. Ch. 62. S. 2. [in Ukrainian].

Novynky. Robitnyky v Stanislavovi khotily shche 8 hrudnia s. r. sklykaty zbory robitnykiv i selian v spravi zahalnoho holosovania y svobody prasy. Dilo. 1891. 18 (30) hrudnia. Ch. 283. S. 3. [in Ukrainian].

Viche v Stanislavovi. Batkivshchyna. 1892. 3 (15 lypnia). Ch. 27. S. 133-134. [in Ukrainian].

Viche narodne v Stanyslavovi vypalo vchera... Dilo. 1892. 23 chervnia (5 lypnia). Ch. 141. S. 1. [in Ukrainian].

Postanovy narodni, shcho yikh povynen znaty na teper kozhdyi Rusyn. Referat d-ra Kostia Levytskoho na vichu v Stanislavovi. Batkivshchyna. 1892. 10 (22 lypnia). Ch. 28. S. 141-142. [in Ukrainian]. 
Pos. I. Huryk pered vybortsiamy. Dilo. 1895. 24 maia (5 chervnia). Ch. 113. S. 2-3. [in Ukrainian].

Po vyborakh. Batkivshchyna. 1895. 16 (28) veresnia. Ch. 18. S. 133-135. [in Ukrainian]. Ukrainian].

Koho vybrano do soimu z hromad silskykh? Batkivshchyna. 1895. 16 (28) veresnia. Ch. 18. S. 135. [in Ukrainian].

Yak perevelys vybory posliv? Z Stanyslavova pyshut nam... Dilo. 1895.7 (19) zhovtnia. Ch. 225. S. 1-2. [in

Novynky i vsiachyna. Do vsikh Rusyniv i vsikh khliborobiv Stanyslavivskoho povitu! Batkivshchyna. 1896. 16 (28) serpnia. Ch. 16. S. 127. Ukrainian].

Povitove viche narodne v Stanyslavovi... Batkivshchyna. 1896. 1 (13) veresnia. Ch. 17. S. 130-132. [in

Rukh vyborchii. Z Stanyslavova pyshut nam: V okruzi vyborchom Stanyslaviv-Bohorodchany-Tovmach-Nadvirna rukh vyborchii $-\mathrm{z}$ viymkoiu povita nadvirnianskoho - dosyt zhyvyi. Dilo. 1897. 25 sichnia (6 liutoho). Ch. 20. S. 1. [in Ukrainian].

Rukh politychnyi ruskoho selianstva. V Chernevi pid Stanyslavovom maly vidbuty sia pravybory... Svoboda. Pysmo politychne, prosvitne i hospodarske dlia narodu. 1897. 27 liutoho (11 marta). Ch. 9. S. 71. [in Ukrainian].

Shche protsesy za vybory. II. Sprava cherniivska. Svoboda. Pysmo politychne, prosvitne i hospodarske dlia narodu. 1897. 19 chervnia (1 lypnia). Ch. 25. S. 194. [in Ukrainian].

Z rukhu vyborchoho. Z Stanyslavova pyshut nam: Pry asystentsiy viyska vidbuly sia pravybory v selakh pid Stanyslavovom v Uhrynovi dolishnim, v Yamnytsy i Krekhyvtsiakh. Dilo. 1897. 25 liutoho (9 marta). Ch. 45. S. 2. [in Ukrainian].

Vybory v V-oi kuriy. (VIII. Stanyslaviv, Halych; Rohatyn, Burshtyn; Pidhaitsi, Vyshnivchyk; Buchach, Zolotyi Potik, Manastyryska; Tovmach, Tysmenytsia, Otyniia). Dilo. 1897. 28 liutoho (12 marta). Ch. 48. S. 1-2. [in Ukrainian].

Novyny. Vyslid vyboriv z kuriy chetvertoy... Svoboda. Pysmo politychne, prosvitne i hospodarske dlia narodu. 1897. 6 (18) marta. Ch. 10. S. 79. [in Ukrainian].

Rukh politychnyi, prosvytnyi i ekonomichnyi ruskoho narodu. V stanislavivskim poviti. Dnia 10 liutoho vidbude sia v Stanislavovi viche... Svoboda. Pysmo politychne, prosvitne i hospodarske dlia narodu. 1898. 15 (27) sichnia. Ch. 3. S. 22. [in Ukrainian].

V stanislavivskim poviti. Viche okruzhne z 10 liutoho vypalo duzhe dobre. Svoboda. Pysmo politychne, prosvitne y hospodarske dlia narodu. 1898. 12 (24) liutoho. Ch. 7. S. 53-54. [in Ukrainian].

Viche v Stanyslavovi. Dilo. 1898. 6 (18) liutoho. Ch. 28. S. 1. [in Ukrainian].

Prosvitnyi, ekonomichnyi i politychnyi rukh sered nashoho narodu. V Stanislavivskim poviti proiavyv sia v poslidnykh chasakh sylnyi rukh prosvitnyi, ekonomichnyi i politychnyi. Svoboda. Pysmo politychne, prosvitne i hospodarske dlia narodu. 1900. 11 (24) maia. Ch. 19. S. 3.

Dopysy pro vyborchyi rukh. Zi Stanislavivshchyny. (Bilshe kandydativ, yak komitetovykh!). Svoboda. Pysmo politychne, prosvitne i hospodarske dlia narodu.. 1900. 1 (25) zhovtnia. Ch. 41. S. 3. [in Ukrainian].

Vyborchyi rukh. P. Yosyf Huryk khlopskyi kandydat na 5-tu kuryiu Stanislaviv i t. d. ... Svoboda. Pysmo politychne, prosvitne i hospodarske dlia narodu. 1900. 23 lystopada (6 hrudnia). Ch. 47. S. 3-4. [in Ukrainian].

Chyselni vykazy z vyboriv (v V-ii kuryi). Svoboda. Pysmo politychne, prosvitne y hospodarske dlia narodu. 1900. 8 (21) hrudnia. Ch. 49. S. 1-2. [in Ukrainian].

Chyselni vykazy z vyboriv (v IV-tii kuryi). Svoboda. Pysmo politychne, prosvitne $i$ hospodarske dlia narodu. 1900. 8 (21) hrudnia. Ch. 49. S. 2. [in Ukrainian].

Pohrom! Vybory v kuryi khlopskii v ruskii chasty kraiu... Svoboda. Pysmo politychne, prosvitne $i$ hospodarske dlia narodu. 1901. 23 serpnia (5 veresnia). Ch. 34. S. 1. [in Ukrainian].

Povyborchi pysma. Iz Stanyslavova pyshut nam... Dilo. 1901. 30 serpnia (12 veresnia). Ch. 195. S. 2.

Dopysy. Zi Stanislavivshchyny. "Razom syly spoluchite, dobro bude vam". Svoboda. Pysmo politychne, prosvitne i hospodarske dlia narodu. 1901. 30 serpnia (12 veresnia). Ch. 35. S. 3.

$\mathrm{Z}$ narodnykh vich i zboriv. Viche v Stanyslavovi vidbulo sia d. 12 s. m. ... Svoboda. Pysmo politychne, prosvitne i hospodarske dlia narodu. 1901.13 (26) hrudnia. Ch. 50. S. 2. [in Ukrainian]. Ukrainian].

Novynky. Narodni vicha v d. 28 padolysta. Dilo. 1905. 19 padolysta (2 hrudnia). Ch. 259. S. 3. [in

Narodni vicha i manifestatsyi. V stanyslavivskim poviti d. 17. s. m. malo vidbuty v Chukalivtsi viche... Dilo. 1906. 9 (22) sichnia. Ch. 6. S. 2. [in Ukrainian].

Narodni vicha i manifestatsyi. V stanyslavivskim pov. vidbuly sia d. 21. s. m. dovirochni zbory... Dilo. 1906. 17 (30) sichnia. Ch. 13. S. 2. [in Ukrainian]. 
Vicha okruzhni. Viche okruzhne v Stanyslavovi... Dilo. 1906. 18 (31) sichnia. Ch. 14. S. 2. [in Ukrainian].

Vyborchi okruhy. III. Dilo. 1906. 10 (23) martsia. Ch. 47. S. 1. [in Ukrainian].

Vyborchi okruhy v Halychyni. Dilo. 1906. 30 maia (12 chervnia). Ch. 109. S. 1. [in Ukrainian].

Vidozva. Novyi vyborchyi zakon oderzhav tsisarsku sanktsyiu. Svoboda. Politychna, prosvitna $i$ hospodarska chasopys. 1907. 14 liutoho. Ch. 7. S. 1-2. [in Ukrainian].

Oholoshenie. Narodnyi Komitet yako nachalna ekzekutyva narodnoho (natsionalno-demokratychnoho) storonnytstva... Dilo. 1907. 20 tsvitnia. Ch. 80. S. 1. [in Ukrainian].

Peredvyborchyi rukh. Z mista Stanyslavova. Ruskym kandydatom z mista Stanyslavova postavyla tamoshna organizatsyia mistseva... Dilo. 1907. 21 martsia. Ch. 54. S. 2. [in Ukrainian].

Peredvyborchyi rukh. V spravi aktsyi vyborchoi v okruzi Stanyslaviv-Tovmach-Obertyn i t. d. oderzhaly my sliduiuchu statiu... Dilo. 1907. 4 maia. Ch. 90. S. 2-3. [in Ukrainian].

Kilko khto distav holosiv dnia 17 s. m. Svoboda. Politychna, prosvitna i hospodarska chasopys. 1907. 21 maia. Ch. 21. S. 2. [in Ukrainian].

Vybory. Z mista Stanyslavova: Stanyslavivska mistseva organizatsyia nashoho natsyonalnodemokratychnoho storonnytstva rishyla... Dilo. 1907. 23 maia. Ch. 104. S. 2. [in Ukrainian].

Opovishchenie z okruha vyborchoho ch. 59. Svoboda. Politychna, prosvitna i hospodarska chasopys. 1907. 28 maia. Ch. 23. S. 3. [in Ukrainian]. Ukrainian].

Vybory. Vyborchi rozboi. Iz Stanyslavova donosiat... Dilo. 1907. 30 maia. Ch. 110. S. 2. [in

Vybory v 1907-im rotsi. Okruh 59. Stanyslaviv, Tovmach i t. d. Svoboda. Pysmo politychne, prosvitne $i$ hospodarske dlia narodu. 1911. 3 maia. Ch. 19. S. 5. [in Ukrainian].

32 ruskykh posliv v avstriiskii derzhavnii radi. Svoboda. Pysmo politychne, prosvitne i hospodarske dlia narodu.1907. 6 chervnia. Ch. 25. S. 5. [in Ukrainian].

Vcherashni vybory. Dilo. 1908. 13 (28) liutoho. Ch. 43. S. 1. [in Ukrainian].

Vybory z halytskykh mist. Dilo. 1908. 19 liutoho (3 martsia). Ch. 48. S. 1. [in Ukrainian].

Vyborchyi rukh. Z okruha 59-oho (Stanyslaviv, Tovmach i t. d.). Svoboda. Politychna, prosvitna $i$ hospodarska chasopys. 1911. 5 maia. Ch. 20. S. 3.

Vykaz holosovania. Okruh 59. Stanyslaviv, Tovmach i t. d. Svoboda. Politychna, prosvitna $i$ hospodarska chasopys. 1911. 21 chervnia. Ch. 32. S. 2. [in Ukrainian]. Ukrainian].

Vybory v Skhidnii Halychyni. Miiski okruhy. Okruh 14. Dilo. 1911. 8 (21) chervnia. Ch. 135. S. 3. [in

Vykaz druhoho holosovania z dnia 26-ho s. m. v sykh okruhakh, de v sei ponedilok, dnia 3-ho lypnia maiemo vybraty 18 nashykh posliv. (Okruh 59. Stanyslaviv-Tovmach-Obertyn i t.d). Svoboda. Politychna, prosvitna i hospodarska chasopys. 1911. 29 chervnia. Ch. 34. S. 3. [in Ukrainian].

Kinets vyboriv v Skhidnii Halychyni. Okruh vyborchyi ch. 59. (Stanyslaviv, Tovmach, Bohorodchany, Yezupil). Dilo. 1911. 21 chervnia (4 lypnia). Ch. 146. S. 2. [in Ukrainian].

24 ukrainski posly... Svoboda. Politychna, prosvitna i hospodarska chasopys. 1911. 6 lypnia. Ch. 35. S. 1. Dnia 12 liutoho s. r. o 12. hod. v poludne vidbulo sia v Stanyslavovi viche pid holym nebom v spravi soimovoi vyborchoi reformy. Dilo. 1912. 3 (16) liutoho. Ch. 36. S. 3. [in Ukrainian].

Vichevyi rukh. Dilo. 1912. 11 (24) maia. Ch. 115. S. 5. [in Ukrainian].

Nashi kandydatury. Svoboda. Politychna, prosvitna i hospodarska chasopys. 1913. 25 chervnia. Ch. 26. S. 2. [in Ukrainian].

Vybory z silskoi kuryi. Svoboda. Politychna, prosvitna i hospodarska chasopys. 1913. 3 lypnia. Ch. 27. S. 2. [in Ukrainian].

Vcherashni vybory. Dilo. 1913. 18 chervnia (1 lypnia). Ch. 144. S. 1-3. [in Ukrainian]. Ukrainskyi Narode! Dilo. 1914. 21 lypnia (3 serpnia). Ch. 171. S. 1. [in Ukrainian]. 